\title{
Chloroplast DNA variation of white oaks in the alpine region
}

\author{
U.M. Csaikl ${ }^{\text {a,** }}$, K. Burg ${ }^{\text {a }}$, S. Fineschi ${ }^{\text {b }}$, A.O. König ${ }^{\text {, }}$, G. Mátyás ${ }^{\text {d,1 }}$, R.J. Petit ${ }^{\mathrm{e}}$ \\ ${ }^{\mathrm{a}}$ ARCS, Austrian Research Center Seibersdorf, A-2444 Seibersdorf, Austria \\ ${ }^{\mathrm{b}}$ CNR Istituto per l'Agroselvicoltura, via Marconi 2, I-05010 Porano TR, Italy \\ ${ }^{\mathrm{c}}$ Institute of Forest Genetics, Sieker Landstrasse 2, D-22927 Grosshansdorf, Germany \\ ${ }^{\mathrm{d}}$ Swiss Federal Research Institute, WSL, Division of Biodiversity, Zürcherstrasse 111, CH-8903 Birmensdorf, Switzerland \\ ${ }^{\mathrm{e}}$ Institut National de la Recherche Agronomique, Station de Recherches Forestières, BP 45, F-33611 Gazinet Cedex, France
}

\begin{abstract}
After the last glacial maximum the Alps have represented a major obstacle to the recolonisation of central and northern Europe by flora and fauna surviving in southern refugia. It is also believed that the Alps may have acted as a temporary refugia for some species, harbouring significant genetic variation or allowing the evolution of new genotypes and subspecies. To examine this possibility for white oak species, a total of 1375 samples from 292 locations were sampled in alpine and flanking regions of Austria, France, Germany, Italy and Switzerland and were assessed for cpDNA variation. Of the oak samples taken, throughout the entire alpine area Quercus robur was found most frequently. Quercus pubescens, widespread in Switzerland, Italy and up to the northern part of the French Alps was found south of $47^{\circ} \mathrm{N}$ and thus absent from Germany and sparse in Austria. Quercus petraea was mainly found in the parts of the Alps west of $12^{\circ} \mathrm{E}$. Absent in the high elevations of the Austrian Alps $Q$. petraea and subspecies can be found at the eastern flank of the Alps. A total of 11 different haplotypes were found within the alpine area. Most frequent are different members of lineage A (common in the Balkan refugial area) with haplotype 7 found in $64 \%$ of the sample set. Haplotype 5, a more eastern member of the lineage, was found at the eastern flank of the Alps. Approximately $22 \%$ of the samples belonged to lineage C (from the Italian refuge), almost all of them were haplotype 1 with the majority crossing the Alps in Switzerland at the Simplon pass. Haplotype 2, the more eastern member of lineage $\mathrm{C}$ originating in Italy, is found at low frequency to the east of the Alps and in the Danube valley. Oak from refugial areas in Spain (lineage B) had only a limited impact on the alpine region. In spite of the historical anthropogenic influence in the alpine region, clear tracks of recolonisation were uncovered. In particular, the path of northward migration of oaks from Italy and the major route north of the Alps were clearly elucidated, confirming earlier assessment of pollen core data. However, the direction of migration (east to west or west to east) of oaks from the Balkan (haplotype 7) around the Alps still needs to be resolved. (C) 2002 Elsevier Science B.V. All rights reserved.
\end{abstract}

Keywords: Chloroplast DNA; Quercus robur; Quercus petraea; Quercus pubescens; PCR-RFLP; Phylogeography; Postglacial recolonisation; Ice age refugia

\footnotetext{
${ }^{*}$ Corresponding author. Tel.: +43-2254-780-3524; fax: +43-2254-780-3653.

E-mail address: ulrike.csaikl@arcs.ac.at (U.M. Csaikl).

${ }^{1}$ Present address: University Children's Hospital, University of Zurich, Division of Metabolism and Molecular Pediatrics, Steinwiesstrasse 75, CH-8032 Zürich, Switzerland.
}

\section{Introduction}

During glacial periods, the growing seasons (interstadials) in northerly latitudes have been too short to support the growth of most tree species which are believed to have survived the ice ages in sheltered refugia, in more southerly locations (Küster, 1997a). In many regions of the northern hemisphere with arctic 
climate during glacial times and moderate climate during interglacials, the postglacial expansion of forest vegetation was largely unhindered by physical obstacles. This was the case in northern America and eastern Asia, where the major mountain ranges run in a north-south orientation. However, in Europe the major mountain ranges are orientated in an east-west direction. Mountains such as the Pyrenees, the French Massif Central, the Alps and the Carpathians, present significant barriers to the postglacial northward expansion of vegetation. The Alps with mountain peaks of well over $3000 \mathrm{~m}$ and passes over $2000 \mathrm{~m}$ present a formidable barrier to the migration of animal as well as plant species. Potential migration routes, such as the Burgundy gate between the Vosges and the Jura in the west and especially the eastern flank of the Alps, must have delayed or may even have prevented the northern colonisation of the vegetation.

During the Younger Dryas cold period (11000$10000 \mathrm{BP})$ a return to cold and dry conditions probably prevented the growth of oaks in northerly latitudes and lead to the extinction of any existing populations north of the main European mountain ranges (Brewer et al., 2002). However, for the alpine mountain range, with attracted higher levels of precipitation at this time, the possibility remains that they could have acted as temporary refugia, supporting forest populations during the short, climatically unfavourable late glacial stadial (Brewer et al., 2002).

In European forests, oaks are economically and ecologically important species. Human impact as well as survival during and recolonisation after the last ice age will have shaped the current spatial patterns of variation found in this species. Oaks were present south of the Alps as early as $11500 \mathrm{BP}$, while their presence on the northern slopes is dated around 9000 BP (Burga and Perret, 1998; Brewer et al., 2002). Around 10000 BP climatic conditions in the alpine area were very similar to those we experience today (Patzelt, 1972, 1980). More recently, due to natural fluctuation in climate, the temperatures have been intermittently even warmer than today leading for instance to findings of spruce close to the Simmingjoch (Austria, just north of the Brenner pass) at $2450 \mathrm{~m}$ which is $350 \mathrm{~m}$ above the current timber limit (Kral, 1994). The first findings of oaks in the Danube valley date to approximately $10000 \mathrm{BP}$ (Küster, 1996). Between 9000 and 7500 BP mixed oak forests were present up to $1400 \mathrm{~m}$ in the eastern flank of the Alps, while in southern Austria (Carinthia), the Norway spruce belt seems to have prevented the mixed oak forest occurring any higher than $1000 \mathrm{~m}$ (Küster, 1996). From 7500 to 4500 BP the timber limit was about $200 \mathrm{~m}$ higher than it is today (Küster, 1996) and, forests covered the Alps up to $2000 \mathrm{~m}$ between 4500 and 2500 BP (Küster, 1996; Burga and Perret, 1998). At the edges of the Alps there was a wide, mixed area connecting the oak-rich flatlands with the coniferous tree dominated highlands of the Alps. In the lowlands, in addition to oaks, other species that are characteristic of oak mixed forest become established at this time.

\subsection{Possible anthropogenic influence}

The anthropogenic influence on the natural vegetation started as early as $7000 \mathrm{BP}$ in central Europe (Küster, 1996). Around 7000 BP mud brick tell settlements began establishing along the Danube into Hungary (Barraclough, 1983). Settlements that formed further north changed in structure over time to wooden longhouses and by $6000 \mathrm{BP}$ had established in the foothills and lower slopes of the Alps. An increasing human population placed pressure on native woods, particularly in the more fertile areas, and land was progressively converted to cultivation. During this time, oak forests close to settlements were probably used as grazing woodland. The extraction of timber, firewood, as well as foliage hay would have provided additional pressures on existing forests (Haas and Rasmussen, 1993; Richoz and Haas, 1995; Küster, 1995). In prehistoric times, settlements practised shifting cultivation and thus pioneering clear-cuts were only established for a restricted time before moving onto new fertile land. As a consequence, it is likely that all forests in settled regions of central Europe have evolved in the secondary succession from a former agricultural landscape (Küster, 1995). Frequently, settlements were built where oak was numerous, but in secondary succession other tree species were favoured due to the lack of competition with mature oaks, contrary to the situation in natural forests (Küster, 1996). Prehistoric practices also favoured other tree species, e.g. beech in middle Europe (Küster, 1996, 1997b), hornbeam in eastern Europe (Ralska-Jasiewicz, 1964) and Norway spruce in the western foothills of the Alps (Markgraf, 1970, 1972). 
Abundant ores of copper near the settlements lead to the discovery of properties of metal. During the Bronze and Iron Ages, the Celts inhabiting the alpine area in Austria and Switzerland were industrious miners, and mining centres were established as early as $4000 \mathrm{BP}$ and were highly developed by $2500 \mathrm{BP}$ in the alpine area (Burga and Perret, 1998). By this time, mines dug down to several hundreds of meters were common below the surface of the Alps. This type of mining is very timber intensive, both in terms of land clearance and for construction. After an alpine valley had been depleted of trees, mines were relocated, leaving large areas of the mountains barren of forest. In addition, these areas tended to be left for livestock use, which did not favour natural tree regeneration, particularly oaks (Kral, 1994).

Economic and cultural contact between the extremes of the ancient world reached its height in the 2 nd century A.D. The north-south trade routes in the region at that time, followed easily negotiable, natural passes across the Alps. A major east-west connection went along the Danube and northern flanks of the Alps. As oak is an important timber tree and acorns were a valuable food source for livestock, it is likely that acorns were also transferred along regional trading routes at this time. So far it has been impossible to distinguish the spread of oak on trading routes and natural spread of seed because both would follow identical routes over the lowest passes and then would simply follow the valleys in mountainous areas. An additional impact on the natural distribution of oak came during Roman times (approximately 20001600 BP), when species like Castanea sativa and Vitis vinifera as well as Juglans regia were introduced to large areas of the Swiss region (Burga and Perret, 1998). These introduced species tended to be planted in areas of former oak forest due to the similar ecological demands of species (Meyer, 1937; Landolt, 1977). A considerable lowering of the timber limit during that time was probably due to human impacts and climatic changes (Drack and Fellmann, 1988; Kral, 1994; Burga and Perret, 1998). From the middle ages onwards, changes in political systems lead to people of central Europe remaining more fixed in settlements. As the spread of beech is favoured in secondary succession, establishment of permanent settlements is the base for today's ratio of oak, beech and hornbeam (Küster, 1996).

\subsection{The situation today}

Mixed oak forest containing Quercus petraea and Quercus robur is rare in Italy and mostly limited to western parts. In forests where $Q$. petraea predominated, C. sativa and Betula pendula are also common tree components. This formation is typical in the prealpine region from the border of France to Switzerland (Ticino). On the eastern side of the Alps, mixed oak forests are partially degraded as a consequence of human activities where most forests are coppiced and Pinus nigra has been planted in large areas (Pignatti, 1998).

Over the last 1000 years the area covered by forests in Austria has reduced from 75 to approximately $45 \%$ (Kral, 1994). During this time span the component of coniferous trees has increased from 68 to $85 \%$, while that of oak has reduced from 8 to only $1 \%$ (Kral, 1994). The forests in the alpine area consist mainly of coniferous trees and oak is generally limited to rivers, valleys and the outskirts of the Alps. Throughout Austria, at altitudes up to $600 \mathrm{~m}$, oak can be found as approximately $1 \%$ pure stands, $6 \%$ individual trees and $16 \%$ mixed populations. At elevations of 600 $900 \mathrm{~m}$, roughly $1 \%$ of oak occurs as single trees and $1 \%$ in mixed stands. From 900 to $1200 \mathrm{~m}$, oak is mainly found as single trees or occasionally as small groups. Altitudes over $2100 \mathrm{~m}$ are usually treeless (Schadauer, 1994).

In Switzerland, oak accounts for approximately $2 \%$ of all forest trees with $Q$. robur being only half as frequent as Q. petraea (Brändli, 1996). Both species are distributed throughout the country but are most common in the Swiss midland. Individual oak trees can be found up to $1450 \mathrm{~m}$. The upper limit for stands of $Q$. robur is $600 \mathrm{~m}$ with $Q$. petraea occurring approximately 100-200 m higher, whilst Quercus pubescens occurs up to 1200 m (Leibundgut, 1991; Brändli, 1996).

\section{3. cpDNA analysis as a tool to trace postglacial migration routes}

In angiosperms, cpDNA is generally maternally inherited (e.g. Corriveau and Coleman, 1988) and thus provides a seed-specific marker. Both in controlled crossings between $Q$. robur (female) and $Q$. petraea (male) (Dumolin et al., 1995) and in population studies (Dumolin-Lapègue et al., 1998) there is no 
evidence for pollen-mediated transfer of cpDNA into the next generation. Thus there is no possibility for the recombination between maternal and paternal cpDNA types during ovule fertilisation. Recombination events can only take place between different cpDNA genomes of the same cell and could be an important mechanism of evolutionary change in this molecule (Gillham, 1994; Kanno et al., 1997; Higgs et al., 1998). In addition, cpDNA has a low mutation rate (Zurawski et al., 1984; Gaut et al., 1996; Wolfe et al., 1997; Lynch and Blanchard, 1998) and in conjunction with its maternal inheritance, make it a suitable marker for following seed movement and retracing historical postglacial migration events (e.g. Petit et al., 1993; Le Corre et al., 1997). DumolinLapègue et al. (1997) defined 26 different cpDNA types for European white oak species. After phylogenetic analysis, types could be assigned to three distinct lineages, which characterise the three European glacial refugia areas of Spain, Italy and the Balkans. The main body of the 'Atlantic lineage' (lineage B) is far to the west of the Alps, while the 'Italian' (lineage C) is found from southern Italy up to Scandinavia. The members of lineage A are found as far east as the Balkan refugial areas, but have spread as far west as the northern border of Spain and as far north as Scandinavia. So far only a few individuals of the Balkan lineage have been found in south of the Alps.

In the work presented here, we want to present a more detailed description of cpDNA variation occurring in oak found in the alpine area. We aim to retrace the main recolonisation routes in this area and determine where oak was able to cross the Alps from the south. In addition, we want to see if the main track between Spain and the Balkans bridged the alpine ridge to the north or south. Finally, cpDNA haplotyping will help to identify human introductions and naturally established oak within the alpine area and will contribute significantly to the conservation and management of its genetic resources.

\section{Material and methods}

\subsection{Collection, transport and storage of the material}

Twigs bearing leafs were collected from oak trees. The base of the twigs were wrapped in damp newspaper and placed in plastic bags labelled with information regarding the location. Bags were stored cool to keep them fresh during transportation to the laboratory for molecular analysis where they were either used directly or stored at -20 or $-80{ }^{\circ} \mathrm{C}$. If possible five trees per population were selected being separated by a $50 \mathrm{~m}$ minimal distance, avoiding trees of obvious or presumed artificial origin. In some cases, depending on circumstances, there may be more or less trees per location. Collections at a minimum distance of $50 \mathrm{~km}$ between locations were attempted, but in some cases it was impossible due to lack of oak trees.

\subsection{Oak species determination}

Three species have been collected and identified on the basis of leaf characters (for reference, see, e.g. Dupouey and Badeau, 1993; Bussoti and Grossoni, 1997), and knowledge gained during assessment of population samples of mixed species (Mariette et al., in preparation). Additionally, in Switzerland the shoot was examined for the presence or absence of two types of trichomes according to Aas (1998) and Müller (1999) (for details, see Mátyás, 1999). In some oak stands species identification was extremely difficult because of the presence of individuals with intermediate traits. If classification within the complicated systematics of the genus Quercus did not allow the precise species identification, the attribution of the species was made mainly based on morphological affinity on the basis of the traits most similar to one species. In $2 \%$ of the entire sample set individuals have been described as intermediates.

\section{3. cpDNA analysis}

Samples were processed in five different laboratories, using primer pairs DT and CD cut with restriction enzyme TaqI, AS in combination with HinfI, and TF with AluI as outlined in Petit et al. (2002). The primers were designed by Taberlet et al. (1991) and Demesure et al. (1995).

The procedures used at ARCS are as described in Csaikl et al. (2001), Bordács et al. (2002) and Jensen et al. (2001). For procedures done in the other labs involved, see Mátyás and Sperisen (2000), Fineschi et al. (2002), König et al. (2002) and Petit et al. (2002). 
The haplotype nomenclatures as defined by Petit et al. (2002) were followed. The description of the electrophoretic profiles of the haplotypes is found in Annexes 1 and 2 of Petit et al. (2002). The composition of the different lineages is indicated in Figs. 1 and 2 of Petit et al. (2002). Several uncommon (referred to as 'rare') haplotypes have been found in the alpine area and will be described together with those found in other areas in more detail by Csaikl and Burg (in preparation). The phylogenetic relationship of rare haplotypes E8, E9 and E16 and their relationship to the standard haplotypes have been examined. All three haplotypes are new members to lineage C. E8 has characteristics of both haplotypes 1 and 32. E9 is identical to haplotype 1 except that the characteristics found for AS are more commonly found in lineage A. Phylogenetically E16, is closer related to E8 than to E9. The haplotype shows quite interesting characteristics: for AS E16 is identical to haplotype 32. for DT it is typical for lineage $\mathrm{C}$, while for $\mathrm{CD}$ it is more typical for lineages A and B (Csaikl and Burg, in preparation). For a basic statistical analysis of the alpine area compared to the rest of Europe, see Petit et al. (2002).

The graphical presentation has been done with the aid of MapInfo Professional Version 5.01 (MapInfo). The geomorphologic map has been taken from Microsoft Encarta 98.

\section{Results}

A total of 1375 oaks were sampled and genotyped from 292 locations across the entire alpine area (Table 1 and Fig. 1). This comprised 75 populations from Austria (23\% of the total) and 31 (11\%) from the Swiss Alps. From the Alps themselves and in flanking areas, $132(45 \%)$ French populations were included as well as $40(16 \%)$ German and $14(5 \%)$ Italian populations.

\subsection{Species distribution}

Q. robur (50\%) was found throughout most of the alpine area. Whereas $Q$. petraea $(22 \%)$ was mainly found in Switzerland and in the eastern flank of the Alps, and $Q$. pubescens (26\%) was restricted to the southern and western parts of the Alps. $Q$. pubescens was widespread in Switzerland and Italy as well as in the northern parts of the French Alps where it was intermingled with the other two oak species. In the southwestern flank of the French Alps, $Q$. pubescens forms pure stands (see Fig. 1). Intermediate forms between $Q$. robur and $Q$. petraea, or $Q$. petraea and $Q$. pubescens, or those that could not be assigned made up $2 \%$ of all samples (Table 1). In Switzerland, a large quantity of samples assessed showed an intermediate form between $Q$. petraea and $Q$. pubescens (Mátyás, 1999). However, all samples included in this study were assigned to one of the three species, $Q$. robur, $Q$. petraea and $Q$. pubescens, because of different methods of species determination.

\subsection{Geographic distribution of haplotypes}

A total of 11 different haplotypes were found in the alpine area (Tables 1 and 2 and Fig. 2). Haplotypes belonging to lineage A were most common and comprised $70 \%$ of all samples (haplotypes 4, 5 and 7). The most frequent haplotype in the alpine area was haplotype 7 which is found in $64 \%$ of the entire sample set. This haplotype was found in all five countries (at a relatively frequency of 56-69\%) and was scattered over the entire area of the Alps just stopping short of the eastern flank of the Alps where haplotype 5, another member of lineage A, is found. While only making up $5 \%$ of the total sample, haplotype 5 reaches $22 \%$ of the Austrian sample set (Table 1). The other members of lineage A are very rare. The two recordings of haplotype 4 in France indicate that these trees are probably introduced.

In total, $22 \%$ of the samples belonged to lineage $\mathrm{C}$ (haplotypes 1 and 2, and the rare haplotypes E8, E9 and E16). Haplotype 1 is the most common and comprises $21 \%$ of the French sample, $36 \%$ of the Swiss, $42 \%$ of the Italian and $30 \%$ of the German sample. However, in Austria only 5\% of the oak surveyed possessed haplotype 1, but two main clusters were obvious. The first grouping is found close to the Danube at the northern flank of the Alps and the second in populations close to the Slovenian border where so far only oaks of lineage A have been found (Kump, Kraigher and Csaikl, unpublished results). Haplotype 2 is rare and found at 2\% in Austria and 1\% in Germany where it is in or close to the Danube valley (Tables 1 and 2 and Fig. 2). Addition to occurrence in 
Table 1

Distribution of haplotypes, lineages and oak species in different countries and the entire alpine region. The number of individuals as well as the percentage in the respective countries and the entire sample set are given ${ }^{\mathrm{a}, \mathrm{b}}$

\begin{tabular}{|c|c|c|c|c|c|c|c|c|c|c|c|c|c|c|c|c|c|c|c|c|c|}
\hline & & \multicolumn{6}{|c|}{ Lineage $\mathrm{C}$} & \multicolumn{4}{|c|}{ Lineage A } & \multicolumn{4}{|c|}{ Lineage B } & \multirow[t]{2}{*}{ Total } & \multicolumn{5}{|c|}{ Oak species } \\
\hline & & H 1 & $\mathrm{H} 2$ & H E8 & H E9 & H E16 & SL C & H 4 & H 5 & H 7 & SL A & H 10 & H 11 & H 12 & SL B & & $\begin{array}{l}Q . \\
\text { robur }\end{array}$ & $\begin{array}{l}Q . \\
\text { petraea }\end{array}$ & $\begin{array}{l}Q . \\
\text { pubescens }\end{array}$ & $\begin{array}{l}\text { Q. robur/Q. } \\
\text { petraea }\end{array}$ & $\begin{array}{l}\text { Q. petraea/Q } \\
\text { pubescens }\end{array}$ \\
\hline \multirow[t]{3}{*}{ Austria } & No. of individuals & 17 & 7 & 2 & 3 & 1 & 30 & 0 & 70 & 220 & 290 & 0 & 0 & 0 & 0 & 320 & 245 & 41 & 0 & 23 & 6 \\
\hline & Total alpine sample set (\%) & 1.2 & 0.5 & 0.1 & 0.2 & 0.1 & 2.2 & 0 & 5.1 & 16 & 21.1 & 0 & 0 & 0 & 0 & 23.3 & 17.8 & 3 & 0 & 2 & 0 \\
\hline & Sample set, Austria (\%) & 5.3 & 2.2 & 0.6 & 0.9 & 0.3 & 9.4 & 0 & 21.9 & 68.8 & 90.6 & 0 & 0 & 0 & 0 & 100 & 76.6 & 12.8 & 0 & 7 & 2 \\
\hline \multirow[t]{3}{*}{ France } & No. of individuals & 132 & 0 & 0 & 0 & 0 & 132 & 2 & 0 & 409 & 411 & 17 & 58 & 5 & 80 & 623 & 183 & 122 & 318 & 0 & 0 \\
\hline & Total alpine sample set (\%) & 9.6 & 0 & 0 & 0 & 0 & 9.6 & 0.1 & 0 & 29.7 & 29.9 & 1.2 & 4.2 & 0.4 & 5.8 & 45.3 & 13.3 & 8.9 & 23.1 & 0 & 0 \\
\hline & Sample set, France (\%) & 21.2 & 0 & 0 & 0 & 0 & 21.2 & 0.3 & 0 & 65.7 & 66 & 2.7 & 9.3 & 0.8 & 12.8 & 100 & 29.4 & 19.6 & 51 & 0 & 0 \\
\hline \multirow[t]{3}{*}{ Germany } & No. of individuals & 64 & 2 & 0 & 0 & 0 & 66 & 0 & 0 & 120 & 120 & 28 & 0 & 1 & 29 & 215 & 170 & 45 & 0 & 0 & 0 \\
\hline & Total alpine sample set (\%) & 4.7 & 0.1 & 0 & 0 & 0 & 4.8 & 0 & 0 & 8.7 & 8.7 & 2 & 0 & 0.1 & 2.1 & 15.6 & 12.4 & 3.3 & 0 & 0 & 0 \\
\hline & Sample set, Germany (\%) & 29.8 & 0.9 & 0 & 0 & 0 & 30.7 & 0 & 0 & 55.8 & 55.8 & 13 & 0 & 0.5 & 13.5 & 100 & 79.1 & 20.9 & 0 & 0 & 0 \\
\hline \multirow[t]{3}{*}{ Italy } & No. of individuals & 26 & 0 & 0 & 0 & 0 & 26 & 0 & 0 & 36 & 36 & 0 & 0 & 0 & 0 & 62 & 25 & 11 & 26 & 0 & 0 \\
\hline & Total alpine sample set (\%) & 1.9 & 0 & 0 & 0 & 0 & 1.9 & 0 & 0 & 2.6 & 2.6 & 0 & 0 & 0 & 0 & 4.5 & 1.8 & 0.8 & 1.9 & 0 & 0 \\
\hline & Sample set, Italy (\%) & 41.9 & 0 & 0 & 0 & 0 & 41.9 & 0 & 0 & 58.1 & 58.1 & 0 & 0 & 0 & 0 & 100 & 40.3 & 17.7 & 41.9 & 0 & 0 \\
\hline \multirow[t]{3}{*}{ Switzerland } & No. of individuals & 55 & 0 & 0 & 0 & 0 & 55 & 0 & 0 & 100 & 100 & 0 & 0 & 0 & 0 & 155 & 59 & 80 & 16 & 0 & 0 \\
\hline & Total alpine sample set (\%) & 4 & 0 & 0 & 0 & 0 & 4 & 0 & 0 & 7.3 & 7.3 & 0 & 0 & 0 & 0 & 11.3 & 4.3 & 5.8 & 1.2 & 0 & 0 \\
\hline & Sample set, Switzerland (\%) & 35.5 & 0 & 0 & 0 & 0 & 35.5 & 0 & 0 & 64.5 & 64.5 & 0 & 0 & 0 & 0 & 100 & 38.1 & 51.6 & 10.3 & 0 & 0 \\
\hline \multirow{3}{*}{ Alpine area } & No. of individuals & 294 & 9 & 2 & 3 & 1 & 309 & 2 & 70 & 885 & 957 & 45 & 58 & 6 & 109 & 1375 & 682 & 299 & 360 & 23 & 6 \\
\hline & Total alpine sample set (\%) & 21.4 & 0.7 & 0.1 & 0.2 & 0.1 & 22.5 & 0.1 & 5.1 & 64.4 & 69.6 & 3.3 & 4.2 & 0.4 & 7.9 & 100 & 49.6 & 21.7 & 26.2 & 1.7 & 0.4 \\
\hline & Lineage $(\%)$ & 95.1 & 2.9 & 0.6 & 1.0 & 0.3 & 100 & 0.2 & 7.3 & 92.5 & 100 & 41.3 & 53.2 & 5.5 & 100 & $\mathrm{n} / \mathrm{a}$ & $\mathrm{n} / \mathrm{a}$ & $\mathrm{n} / \mathrm{a}$ & $\mathrm{n} / \mathrm{a}$ & $\mathrm{n} / \mathrm{a}$ & $\mathrm{n} / \mathrm{a}$ \\
\hline
\end{tabular}

${ }^{a}$ Q. sp. (a): intermediate form between $Q$. petraea and $Q$. pubescens; Q. sp. (b): intermediate form between $Q$. robur and $Q$. pubescens.

${ }^{\mathrm{b}} \mathrm{H}$ : haplotype; SL: sum lineage. 


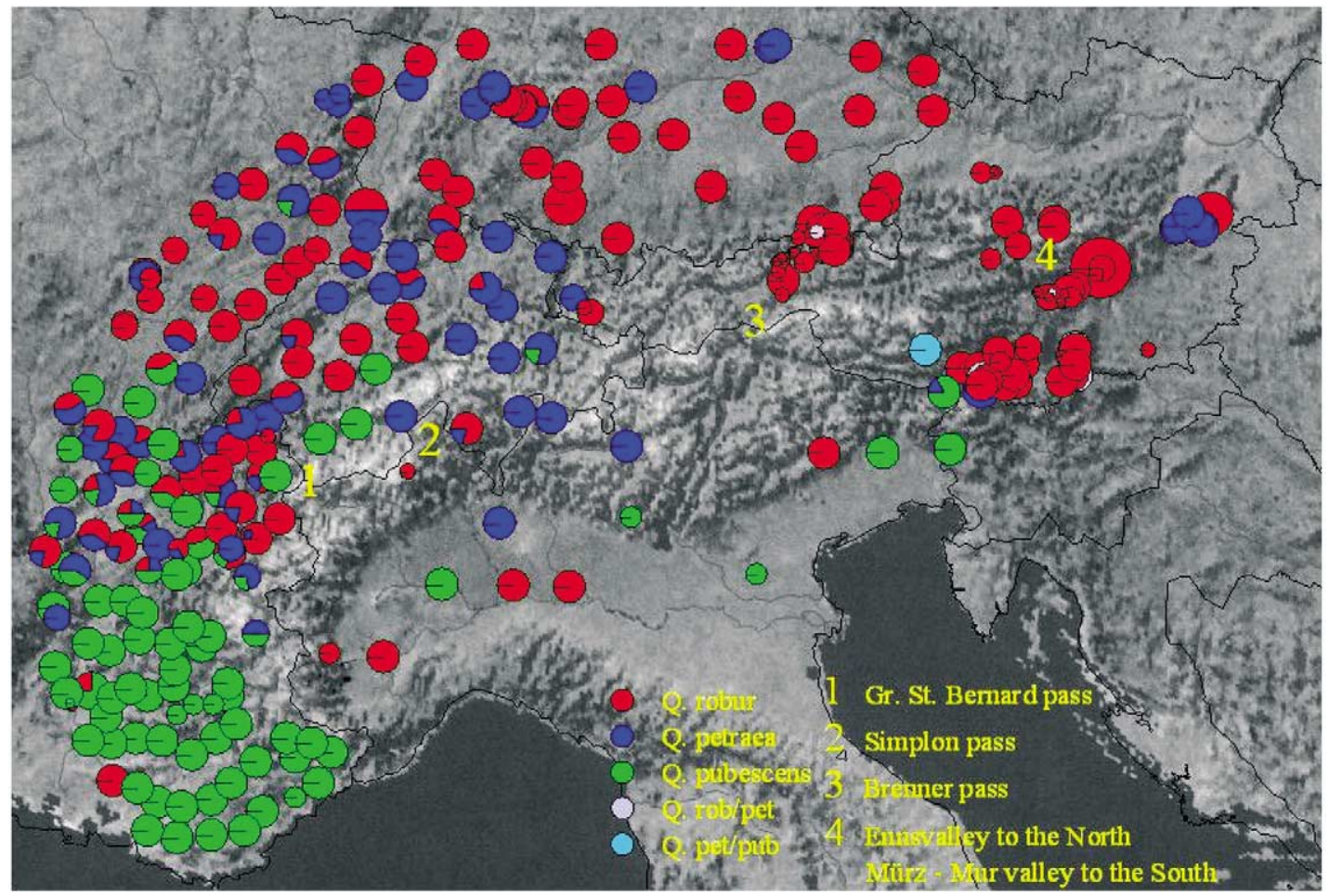

Fig. 1. Species distribution of European white oak in the alpine area. The size of the circles is proportional to the population size investigated. The colour codes for the different species found in each population and the location of some alpine passes are indicated on the graph.

Austria, rare haplotype E8, also a member of lineage $\mathrm{C}$, was found in Scandinavia and the Baltic countries while E9 is found so far in Austria alone. Another rare haplotype, E16, is found in a few individuals in Austria as well as in some provenance trial material of Denmark, Norway and the Netherlands (data not shown). Oak of that haplotype could either be introduced or show a mutation originating in Austria.

Haplotypes of lineage B were very rare within the alpine region (Fig. 2). Haplotypes 10 and 12 were found in Germany and France at low frequency ( 3 and $0.4 \%$, respectively), while haplotype 11 was found only in France (4\%).

Almost all populations possessing different haplotypes are found in a geographic area where the types are found in uniform stands as well (except the one with haplotype 4, see above). Therefore, we considered these mixed populations which are frequently an indicator of allochthonous stands as natural and included these data in the general description of the region.

\subsection{Haplotype distribution within species}

In the entire alpine region, $50 \%$ of the sample set consists of $Q$. robur, $26 \%$ of $Q$. pubescens and $22 \%$ of $Q$. petraea, however, there was a notable difference for the spatial distribution of haplotypes between the species (Tables 1 and 2 and Figs. 1 and 2).

Lineage A: haplotype 7 is found in $65 \%$ of the samples of the alpine area (Table 1). Fifteen per cent of the total is found in $Q$. pubescens, $12 \%$ in $Q$. petraea, $1 \%$ in intermediate forms, with the vast majority (36\%) in Q. robur. Haplotype 5 (5\% of the total sample set) only occurred in Austria and is shared between $Q$. petraea, $Q$. robur and intermediate forms (Q. pubescens was not sampled in Austria) (Table 2).

Lineage B: haplotype 11 represents $4 \%$ of the total sample set but is only found in France. The majority of this haplotype is found in $Q$. petraea $(50 \%)$ and $25 \%$ each in the two other species. As the species distribution (Table 1) is 50\% Q. robur, $22 \%$ Q. petraea and the rest $Q$. pubescens, $Q$. petraea is over 
Table 2

Distribution of haplotypes and lineages in different oak species in different countries and the entire alpine region. The number of individuals as well as the percentage in the respective countries and the entire sample set are given ${ }^{\mathrm{a}, \mathrm{b}}$

\begin{tabular}{|c|c|c|c|c|c|c|c|c|c|c|c|c|c|c|c|c|c|c|c|c|c|c|c|c|c|}
\hline \multirow[t]{4}{*}{ Country } & & \multicolumn{24}{|c|}{ Species } \\
\hline & & \multicolumn{11}{|c|}{ Q. robur } & \multicolumn{5}{|c|}{ Q. petraea } & \multicolumn{5}{|c|}{ Q. pubescens } & \multirow{2}{*}{\multicolumn{3}{|c|}{$\frac{\text { Q. sp. }}{\text { Lineage A }}$}} \\
\hline & & \multicolumn{5}{|c|}{ Lineage C } & \multicolumn{3}{|c|}{ Lineage A } & \multicolumn{3}{|c|}{ Lineage $B$} & \multirow{2}{*}{$\begin{array}{l}\text { Lineage } \\
\mathrm{C}, \mathrm{H} 1\end{array}$} & \multicolumn{2}{|c|}{ Lineage A } & \multicolumn{2}{|c|}{ Lineage B } & \multirow{2}{*}{$\begin{array}{l}\text { Lineage } \\
\mathrm{C}, \mathrm{H} 1\end{array}$} & \multirow{2}{*}{$\begin{array}{l}\text { Lineage } \\
\mathrm{A}, \mathrm{H} 7\end{array}$} & \multicolumn{3}{|c|}{ Lineage B } & & & \\
\hline & & H 1 & H 2 & H E8 & H E9 & H E16 & H 4 & H 5 & H 7 & H 10 & H 11 & H 12 & & H 5 & H 7 & H 10 & H 11 & & & H 10 & H 11 & H 12 & H 7 (a) & H 5 (b) & p) $\mathrm{H} 7$ (b) \\
\hline \multirow{3}{*}{ Austria } & No. of individuals & 17 & 2 & 2 & 3 & 1 & 0 & 25 & 195 & 0 & 0 & 0 & 0 & 30 & 11 & 0 & 0 & 0 & 0 & 0 & 0 & 0 & 6 & 15 & 8 \\
\hline & Total alpine sample set (\%) & 1.2 & 0.1 & 0.1 & 0.2 & 0.1 & 0 & 1.8 & 14.2 & 0 & 0 & 0 & 0 & 2.2 & 0.8 & 0 & 0 & 0 & 0 & 0 & 0 & 0 & 0.4 & 1.1 & 0.6 \\
\hline & Sample set, Austria (\%) & 5.3 & 0.6 & 0.6 & 0.9 & 0.3 & 0 & 7.8 & 60.9 & 0 & 0 & 0 & 0 & 9.4 & 3.4 & 0 & 0 & 0 & 0 & 0 & 0 & 0 & 1.9 & 4.7 & 2.5 \\
\hline \multirow{3}{*}{ France } & No. of individuals & 13 & 0 & 0 & 0 & 0 & 2 & 0 & 142 & 7 & 15 & 4 & 1 & 0 & 87 & 4 & 30 & 118 & 180 & 6 & 13 & 1 & 0 & 0 & 0 \\
\hline & Total alpine sample set (\%) & 0.9 & 0 & 0 & 0 & 0 & 0.1 & 0 & 10.3 & 0.5 & 1.1 & 0.3 & 0.1 & 0 & 6.3 & 0.3 & 2.2 & 8.6 & 13.1 & 0.4 & 0.9 & 0.1 & 0 & 0 & 0 \\
\hline & Sample set, France (\%) & 2.1 & 0 & 0 & 0 & 0 & 0.3 & 0 & 22.8 & 1.1 & 2.4 & 0.6 & 0.2 & 0 & 14.0 & 0.6 & 4.8 & 18.9 & 28.9 & 1 & 2.1 & 0.2 & 0 & 0 & 0 \\
\hline \multirow[t]{3}{*}{ Germany } & No. of individuals & 46 & 2 & 0 & 0 & 0 & 0 & 0 & 105 & 16 & 0 & 1 & 18 & 0 & 15 & 12 & 0 & 0 & 0 & 0 & 0 & 0 & 0 & 0 & 0 \\
\hline & Total alpine sample set (\%) & 3.3 & 0.1 & 0 & 0 & 0 & 0 & 0 & 7.6 & 1.2 & 0 & 0.1 & 1.3 & 0 & 1.1 & 0.9 & 0 & 0 & 0 & 0 & 0 & 0 & 0 & 0 & 0 \\
\hline & Sample set, Germany (\%) & 21.4 & 0.9 & 0 & 0 & 0 & 0 & 0 & 48.8 & 7.4 & 0 & 0.5 & 8.4 & 0 & 7 & 5.6 & 0 & 0 & 0 & 0 & 0 & 0 & 0 & 0 & 0 \\
\hline \multirow[t]{3}{*}{ Italy } & No. of individuals & 11 & 0 & 0 & 0 & 0 & 0 & 0 & 14 & 0 & 0 & 0 & 10 & 0 & 1 & 0 & 0 & 5 & 21 & 0 & 0 & 0 & 0 & 0 & 0 \\
\hline & Total alpine sample set (\%) & 0.8 & 0 & 0 & 0 & 0 & 0 & 0 & 1 & 0 & 0 & 0 & 0.7 & 0 & 0.1 & 0 & 0 & 0.4 & 1.5 & 0 & 0 & 0 & 0 & 0 & 0 \\
\hline & Sample set, Italy (\%) & 17.7 & 0 & 0 & 0 & 0 & 0 & 0 & 22.6 & 0 & 0 & 0 & 16.1 & 0 & 1.6 & 0 & 0 & 8.1 & 33.9 & 0 & 0 & 0 & 0 & 0 & 0 \\
\hline \multirow[t]{3}{*}{ Switzerland } & No. of individuals & 20 & 0 & 0 & 0 & 0 & 0 & 0 & 39 & 0 & 0 & 0 & 30 & 0 & 50 & 0 & 0 & 5 & 11 & 0 & 0 & 0 & 0 & 0 & 0 \\
\hline & Total alpine sample set (\%) & 1.5 & 0 & 0 & 0 & 0 & 0 & 0 & 2.8 & 0 & 0 & 0 & 2.2 & 0 & 3.6 & 0 & 0 & 0.4 & 0.8 & 0 & 0 & 0 & 0 & 0 & 0 \\
\hline & Sample set, Switzerland (\%) & 12.9 & 0 & 0 & 0 & 0 & 0 & 0 & 25.2 & 0 & 0 & 0 & 19.4 & 0 & 32.3 & 0 & 0 & 3.2 & 7.1 & 0 & 0 & 0 & 0 & 0 & 0 \\
\hline \multirow[t]{2}{*}{ Alpine area } & No. of individuals & 107 & 4 & 2 & 3 & 1 & 2 & 25 & 495 & 23 & 15 & 5 & 59 & 30 & 164 & 16 & 30 & 128 & 212 & 6 & 13 & 1 & 6 & 15 & 8 \\
\hline & Total alpine sample set (\%) & 7.8 & 0.3 & 0.1 & 0.2 & 0.1 & 0.1 & 1.8 & 36 & 1.7 & 1.1 & 0.4 & 4.3 & 2.2 & 11.9 & 1.2 & 2.2 & 9.3 & 15.4 & 0.4 & 0.9 & 0.1 & 0.4 & 1.1 & 0.6 \\
\hline
\end{tabular}

${ }^{\mathrm{a}} \mathrm{Q}$. sp. (a): intermediate form between $Q$. petraea and $Q$. pubescens; Q. sp. (b): intermediate form between $Q$. robur and $Q$. pubescens.

${ }^{\mathrm{b}} \mathrm{H}$ : haplotype. 


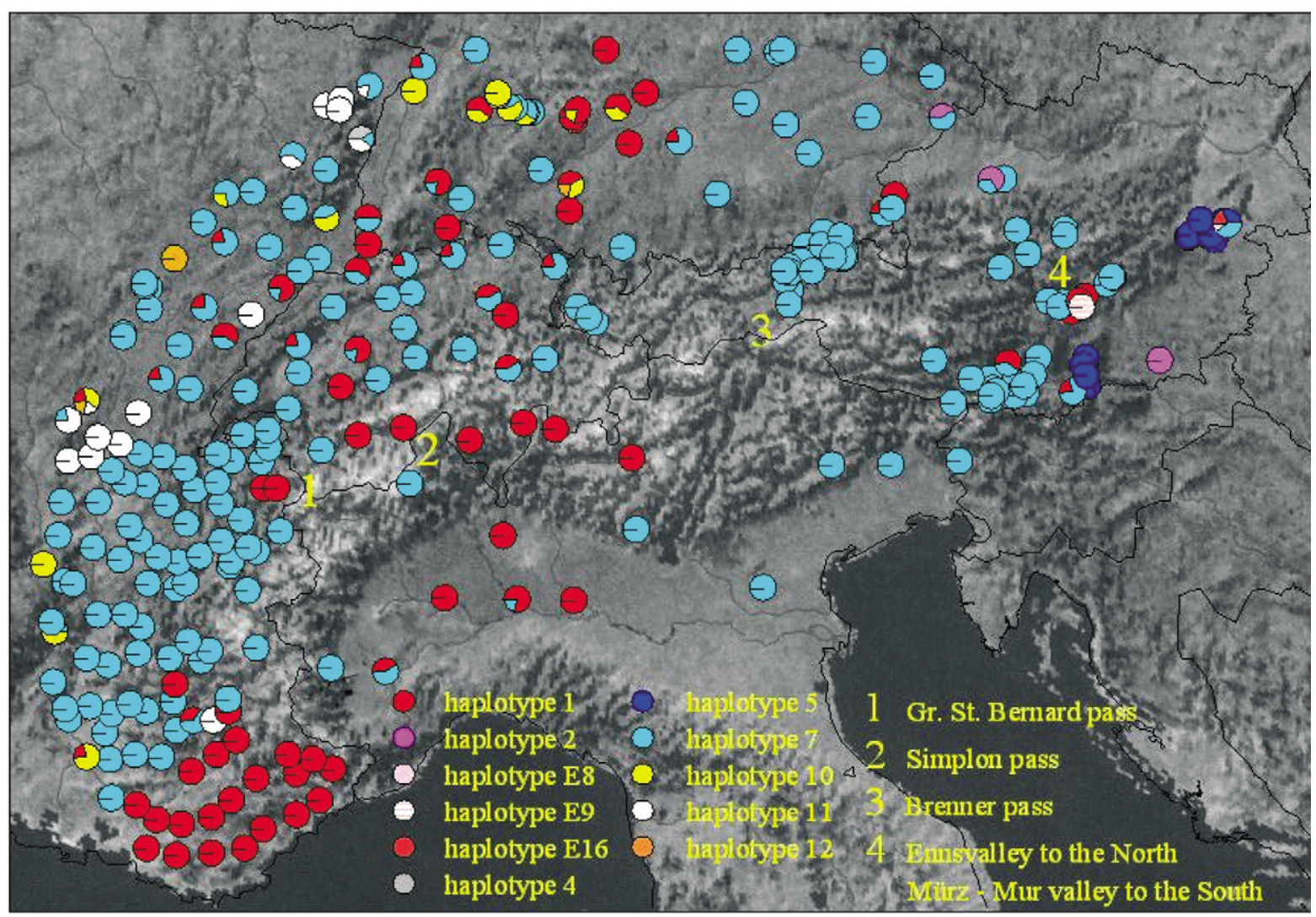

Fig. 2. Haplotype distribution of European white oak in the alpine region. Equally sized circles show composition of the 11 different haplotypes found in populations. The colour codes for the different haplotypes and the location of some alpine passes are indicated on the graph.

represented for haplotype 11. Haplotype 10 is found in all three species in France (seven $Q$. robur, four $Q$. petraea and six $Q$. pubescens individuals), and German samples of $Q$. robur and $Q$. petraea (16 and 15 individuals, respectively). Haplotype 12 is found in a single $Q$. robur individual in Germany, while in France one $Q$. pubescens and four $Q$. robur specimens possessed this type (Table 2).

Lineage C: haplotype 1 (22\% of the total) is found in all species and all countries except in Austria where haplotype 1 is absent from $Q$. petraea. However, this observation is probably due to the fact that there is no $Q$. petraea occurring where haplotype 1 is frequent. Haplotype 2 (1\% of the total) is found in $Q$. robur close to the Danube valley in Austria as well as in Germany where it is more frequent (see König et al., 2002; Csaikl and Burg, in preparation). Haplotype E9 is found in $Q$. robur in an Austrian alpine valley in the southeast together with some of the haplotype 1 . The lineage $\mathrm{C}$ does not spread any further from there so it is quite likely that during the migration to the east of the Alps some members of the lineage $\mathrm{C}$ have been in an isolated area for a quite long time which gave them the chance to evolve. Haplotype E8 is found in a stand at the east flank of the Alps in $Q$. robur as well. Other than that haplotype E8 is found in quite a few of the Austrian populations in the Danube valley (Csaikl and König, 2000) as well as in some parts of Scandinavia and the Baltic countries (see Csaikl et al., 2001; König et al., 2002). The rare haplotype E16, also member of lineage $\mathrm{C}$, is found in one $Q$. robur individual in the same stand as haplotype E8 (Tables 1 and 2 and Figs. 1 and 2). 


\section{Discussion}

As has been found to be the case for other forest tree species, the postglacial recolonisation of oaks into the alpine region is believed to have originated from an Italian refuge and have spread mainly around the Alps (Kral, 1994). The main stream of recolonisation is thought to have proceeded from the south in Italy up to the Alps, then to have continued west to east along the southeastern and northeastern flank of the Alps (Huntley, 1988; Gliemeroth, 1995). Reaching the Danube valley oak from the south would probably have met with oak originating from the Balkan refugia. Another (minor) track could have been from the western refugia along the northern flank of the Alps towards west (Kral, 1979). A direct route through the Alps from south to north that has been documented by fossil pollen records of oak is crossing the Brenner pass $(1371 \mathrm{~m})$ and going through the 'Unterinntal' (Kral, 1994). Evidence from detailed cpDNA investigation in Switzerland show that the Simplon pass $(2006 \mathrm{~m})$ as well as the Grand St. Bernard pass $(2469 \mathrm{~m})$ were probably crossed by oaks (Mátyás and Sperisen, 2000). The finding of fossil spruce close to the Simmingjoch indicates that forest trees must have existed $350 \mathrm{~m}$ above the current timber limit of $2100 \mathrm{~m}$ (Kral, 1994; Schadauer, 1994). Analytical analysis found oak pollen from around 8500-5500 BP in the moors of alpine passes at an altitude of 2100 $2200 \mathrm{~m}$ (Keller, 1932) and thus oak was probably able to pass through these high passes in former times.

\subsection{Species distribution in the alpine region}

In this investigation, $Q$. robur appears to be the predominant oak species. This species is present throughout the Alps and in the flanking regions in quite diversified ecological situations, with the exception of a small area in the southernmost part of the alpine area in France where $Q$. pubescens is common. As a rule $Q$. pubescens is found in the southern rather than in the northern part of the alpine area (south of $47^{\circ} \mathrm{N}$ ), but sometimes at very high altitudes, for instance in Switzerland (1450 m; Leibundgut, 1991). Q. petraea inhabits mainly the western part of the alpine region (west of $12^{\circ} \mathrm{E}$ ). It is found west from the Alps in France and towards the north in Germany. It appears again in the east, near the
Pannonian region where it is also more frequent (data not shown). $Q$. petraea ssp. dalechampii as well as other subspecies belonging to the $Q$. petraea group are found mainly to the east rather than in the western part (Csaikl, unpublished data; Bordács et al., 2002), but the overall frequency in Austria is rather low. Biodiversity is high in the primary full glacial refugia (Hengeveld, 1989; Bordács et al., 2002; Fineschi et al., 2002; Olalde et al., 2002; Petit et al., 2002) thus the occurrence of subspecies in the eastern Austrian Alps is an indicator to support the existence of secondary temporary refugia in the central European mountains as proposed by Brewer et al. (2002).

Oaks are rather sparse in the Italian as well as in the Austrian part of the alpine region. This concords with observations published earlier reporting that $Q$. petraea and $Q$. robur are sporadic over the Italian territory (Pignatti, 1982; Bernetti, 1995; Gellini and Grossoni, 1997). Both species are particularly rare as pure stands, they occur mostly in the form of mixed broadleaf communities. In northern Italy, mixed $Q$. petraea forest represents the transition between the central European mixed oak forest (mostly Fagus sylvatica, Carpinus betulus and Quercus spp.) and the more Mediterranean mixed oak forest, where $Q$. pubescens is prevalent. $Q$. robur requires wet lowlands which have been progressively converted into agricultural fields and pasture; it has, therefore, became particularly rare in northern Italy (Gellini and Grossoni, 1997). Interestingly, only $Q$. robur was found in the Austrian Alps, which are characterised by fairly narrow river valleys surrounded by high mountains. Oak in the Austrian Alps is present only in the river valleys and absent from large areas due to the high altitude of the alpine mountain ridges. About $75 \%$ of the entire Austrian sample is composed of $Q$. robur the rest being made up of $Q$. petraea. While Q. pubescens is quite abundant in Italy, it is more or less absent from Austria. In Switzerland, however, only $25 \%$ of the samples were represented by $Q$. robur, the rest is $Q$. petraea and $Q$. pubescens or individuals morphologically intermediate between $Q$. petraea and $Q$. pubescens, which account for as much as $50 \%$ of all Swiss oaks (Mátyás, 1999).

\subsection{Genetic diversity in the alpine region}

In the present European-wide survey the alpine region was found to possess the lowest level of total 
variability predominated by two haplotypes ( 1 and 7), and representing an intermediate allelic richness suggesting a balanced recolonisation from few refugial areas (Petit et al., 2002). Altogether 11 haplotypes from three lineages $(\mathrm{A}-\mathrm{C})$ were detected in the region (Table 1). Three out of the 11 haplotypes identified were rare haplotypes.

The two predominant haplotypes ( 1 and 7$)$ were found in $85 \%$ of the populations analysed. Haplotype 7 of lineage A had the highest frequency in the alpine region. It is also the most frequent haplotype in Europe and has a distribution ranging from the Pyrenees to the Baltic republics and to the western part of Rumania (Petit et al., 2002). Haplotype 1 of lineage $\mathrm{C}$ ranked as second predominant haplotype in the alpine region; it is also a widespread haplotype in Europe. Its distribution ranges as far south as Sicily all the way up to Scandinavia going east and west of the Baltic Sea. There is a major side branch from northern Italy through France into northern Spain. Haplotypes 10-12 of lineage B represent about $8 \%$ of the populations, however, these haplotypes are underrepresented in comparison to the European average frequency. This is probably due to the fact that none of those types is present in the central Alps. All individuals of lineage $\mathrm{B}$ are found close to other populations with the same haplotypes (see König et al., 2002; Petit et al., 2002) so they may be considered autochthonous.

During our collection oak has not been found at some locations in Austria and Italy still described in recent publications to hold oak stands. Thus, it seems that decrease of oak from the alpine area has continued in recent years. In spite of this and historic depletion of forest resources as described above the majority of oak in the survey can be considered autochthonous. Only a few populations show different haplotypes at one location, a possible indicator for non-native stands (Petit et al., 2002). Of course it is not possible to distinguish between natural stands and populations reforested with local material but as those locations are close to areas where those different haplotypes occur most likely they are also of natural origin.

All of the oak in the survey has been considered autochthonous by experts at the time of collection. As outlined in Section 1 human impact in the whole area has been considerable during the past. Our analysis of cpDNA haplotypes and a comparison with material in different countries proofs that, e.g. oak in the alpine valleys of Austria is not like to be allochthonous. $Q$. robur ssp. salvonica (Slavonian oak) which has been widely used in the past to reforest areas depleted of oak seems to be completely missing in our material because this species shows completely different haplotypes (Bordács et al., 2002).

\subsection{Putative migration routes}

In the alpine region, it is possible to follow the distribution of the two predominant haplotypes (1 and 7). It seems clear that the migration routes of these two haplotypes are crossing in the western Alps region, in Switzerland. Members of lineage B (haplotypes 10-12), however, only reached into France and western Germany in the northern outskirts of the alpine region.

There is a clear track of oak with haplotype 1 (of lineage $\mathrm{C}$ ) leading from south to north through the western Alps in Switzerland (Mátyás and Sperisen, 2000). The few findings of haplotype 1 in the eastern Alps are trapped in different mountain valleys located in Carinthia and Styria in southern Austria. In the Styrian Mürz-Mur valley, we found a rare haplotype (haplotype E9) of lineage $\mathrm{C}$ which could have evolved in this isolated situation. Other lineage $\mathrm{C}$ members (haplotype 2) and/or other rare haplotypes (see Csaikl and Burg, in preparation) are found further east confirming Switzerland as the only crossing area for oak possessing haplotype 1 . It is evident that haplotype 2 could avoid the alpine barrier because of the land bridge which existed in the northern and central part of the present Adriatic sea between the Italian and the Balkan peninsulas (Petit et al., 2002). This hypothesis is supported by the fact that there is no evidence of any members of the lineage $\mathrm{C}$ in the limited sample set from Slovenia analysed so far (Kumpf, Kraigher and Csaikl, unpublished data). Northwards migration of oak possessing haplotype 1 from Italy over the Simplon into Switzerland (Mátyás and Sperisen, 2000) probably has been more successful than attempts in the eastern Alps. One reason could be that the Swiss midlands are wider and climate is more favourable than further east in the Alps. While a direct migration from northern Italy into Switzerland is evident from the data presented we cannot completely rule out migration into Switzerland via France. 
Haplotype 5 is found from the eastern flank of the Alps into Hungary (see also Bordács et al., 2002) as well as in southern Italy (Fineschi et al., 2002). The south-north migration of haplotype 5 in Italy stopped in the northern Apennines $\left(44^{\circ} \mathrm{N}\right)$ and proceeded eastward to reach Slovenia and Croatia (Petit et al., 2002). The possible exchange between the two peninsulas explains the high frequency of haplotype 5 in the southern Italian regions, however, there are still no data on southern Balkan countries. In this sense, we can only speculate on the Balkan or the Italian origin of haplotype 5. Petit et al. (2002) even suggest the hypothesis of the existence of two refugia for this haplotype, one in Italy and one in the Balkans, but this needs further investigation. In the case of haplotypes 4 as well as 2 such migration, from one side to the other one of the Adriatic sea, which may have preceded the last interglacial would have been made easier by the land bridge which was present at this time. Haplotype 7 is found all over the alpine region as well as in neighbouring area. Its frequency in the western as well as in the northern part is rather high. This is in accordance with a putative migration route on the northern flank of the Alps, however, the existence of a southern migration route cannot be excluded. The existence of the latter could account for the presence of this haplotype in the southern valleys of the Alps. On the other hand, our data rather support a migration route of haplotype 7 oak from the northern Alps through the Inn valley and the Brenner towards Italy and not in the opposite direction as suggested by Kral (1994). Although, due to the relatively low frequency of oak investigated in northern Italy this hypothesis needs further confirmation. The southern migration of haplotype 7 oak from the Danube valley into the Enns valley and to the adjacent Mürz-Mur valley cannot be ruled out. However, northern migration from Italy or Slovenia could also be possible. Migration of haplotype 7 oak from or to Switzerland could have taken place at the Grand St. Bernard pass (Mátyás and Sperisen, 2000). Investigations with more refined methodology will have to prove those points.

The occurrence of rare haplotypes is by definition restricted basically to the area of origin - unless by chance they are located in or originate from a seed lot of rather low importance. Otherwise they would have been found in different locations in Europe during our survey. In addition, the fact that the rare haplotypes found are related to haplotypes native to the area let us assume that this oak is also of natural origin. Rare haplotypes probably have developed due to introgression of cytoplasmic genomes across species and the existence of comparatively recent local exchanges in a rather closed in situation, and possibly surrounded by oak established of different haplotypes (DumolinLapèque et al., 1999). The finding of new rare haplotypes in some eastern alpine valleys supports the proposed existence of a secondary temporary refugial area in the alpine region (Brewer et al., 2002) where oak, in the isolated situation of alpine valleys, probably had the chance to evolve to a type slightly modified from the main types.

\section{Conclusions}

In the alpine region, we found three European white oak species. The southwestern part is predominated by $Q$. pubescens, the central alpine region is inhabited nearly exclusively by $Q$. robur, while $Q$. petraea in addition to the western Alps appears again at the lower eastern ridges of the Alps. In spite of the anthropogen influence in the alpine region, starting already in prehistorical times, clear tracks of recolonisation can be described.

The alpine region is dominated by two haplotypes (7 and 1) showing quite distinct migration routes within the region. One clear-cut track of oak possessing haplotype 1 has been found going from the Italian refugial areas in the western Alps through Switzerland into Germany and all the way to Scandinavia. A second track (identified by haplotype 2) must have progressed during prehistoric times through the basin of the northern and central Adriatic sea and found a path clear of the Alps through the Pannonian basin. Other efforts crossing the Alps from the south appear to have been trapped in the Austrian alpine valleys. Attempts by oak of Italian origin to reach the north around the western side of the Alps were stopped in the south of France where they probably encountered oak of lineage A having arrived earlier in the area. This view probably could be strengthened by an investigation of samples from the region with a more refined cpDNA analysis method.

The major track of lineage A (haplotype 7) was found on the northern flank of the Alps in east-western 
(or west-eastern) direction. As some oak possessing haplotype 7 was found south of the Alps as well there is possibly also a minor migration route on the southern flank of the Alps. Clear tracks of haplotype 7 leading through the Alps have not been found and there is no connection in the southwest of the alpine area from Italy to France. Decisions on the origin of the different findings of oak of lineage A, especially south of the Alps and on the direction of the migration can only been made after investigating and comparing more samples in Austria, Italy and surrounding area using a more refined cpDNA analysis method (Csaikl and König, 2000; Csaikl and Burg, in preparation). This would allow a distinction between even close locations (as done in the area north of the Alps) (Csaikl and König, 2000).

Finding of subspecies of $Q$. petraea in the eastern alpine region as well as oak individuals showing rare haplotypes of lineage $\mathrm{C}$ support the existence of a secondary temporary refugia in the alpine area as outlined by Brewer et al. (2002) based on fossil pollen records.

\section{Acknowledgements}

The study has been carried out with the financial support from the Commission of the European Communities, Agriculture and Fisheries (FAIR) specific RTD programme, CT-FAIR1 PL95-0297, "Synthetic maps of gene diversity and provenance performance for utilisation and conservation of oak genetic resources in Europe". It does not necessarily reflect its views and in no way anticipates the Commission's future policy in this area.

Our special thanks goes to the FBVA, Austria, especially A. Bernhardt, Waldbau and K. Schweinzer, Waldinventur and foresters from various Bezirksforstinspektionen and private forest owners in Austria: without their help the collection of local material in Austria would not have been possible. We are grateful to K. Hohl, K. Groppe and N. Ziegler for expert assistance in the laboratories and to A. Lowe and J.S. Jensen for constructive criticism on the previous version of the manuscript.

\section{References}

Aas, G., 1998. Morphologische und ökologische Variation mitteleuropäischer Quercus-Arten: Ein Beitrag zum Verständnis der Biodiversität. IHW-Verlag, Eching, Libri Botanici, p. 19.
Barraclough, G., 1983. Atlas of World History. Times Books Ltd., London.

Bernetti, G., 1995. Selvicoltura Speciale. UTET, Torino.

Bordács, S., Popescu, F., Slade, D., Csaikl, U.M., Lesur, I., Borovics, A., Kézdy, P., König, A.O., Gömöry, D., Brewer, S., Burg, K., Petit, R.J., 2002. Chloroplast DNA variation of white oaks in northern Balkans and in the Carpathian Basin. For. Ecol. Manage. 156, 197-209.

Brändli, U.B., 1996. Die häufigsten waldbäume der schweiz. ergebnisse aus dem landesforstinventar 1983-1985: verbreitung, standort und häufigkeit von 30 baumarten. Ber. Eidgenöss. Forschanst. Wald Schnee Landsch. 342, 107-120.

Brewer, S., Cheddadi, R., de Beaulieu, J.-L., Reille, M., and Data contributors, 2002. The spread of deciduous Quercus throughout Europe since the last glacial period. For. Ecol. Manage. 156, 27-48.

Burga, C.A., Perret, R., 1998. Vegetation und Klima der Schweiz seit dem jüngeren Eiszeitalter. Ott Verlag, Thun, p. 805.

Bussoti, F., Grossoni, P., 1997. European and Mediterranean oaks (Quercus L.; Fagaceae): SEM characterization of the micromorphology of the abaxial leaf surface. Bot. J. Linn. Soc. 124, 183-199.

Corriveau, J.L., Coleman, A.W., 1988. Rapid screening method to detect potential biparental inheritance of plastid DNA and results for over 200 angiosperm species. Am. J. Bot. 75, 14431458.

Csaikl, U.M., König, A., 2000. Genetic types in white oak populations north of the Alps and in the Danube valley. In: Proceedings of the IUFRO Conference (Divisions 2 and 7) on Genetic Response of Forest Systems to Changing Environmental Conditions-Analysis and Management, Freising, September 12-17, 1999. Kluwer Academic Publishers, Dordrecht, 10 pp., in press.

Csaikl, U.M., Glaz, I., Baliuckas, V., Petit, R.J., Jensen, J.S., 2001. Chloroplast DNA variation of white oaks in the Baltic countries and Poland. For. Ecol. Manage., this issue.

Demesure, B., Sodzi, N., Petit, R.J., 1995. A set of universal primers for amplification of polymorphic non-coding regions of mitochondrial and chloroplast DNA in plants. Mol. Ecol. 4, 129-131.

Drack, W., Fellmann, R., 1988. Die Römer in der Schweiz. Konrad Theis Verlag. Raggi Verlag, Stuttgart.

Dumolin, S., Demesure, B., Petit, R.J., 1995. Inheritance of chloroplast and mitochondrial genomes in pedunculate oak investigated with an efficient PCR method. Theoret. Appl. Genet. 91, 1253-1256.

Dumolin-Lapègue, S., Demesure, B., Le Corre, V., Fineschi, S., Petit, R.J., 1997. Phylogeographic structure of white oaks throughout the European continent. Genetics 146, 1475-1487.

Dumolin-Lapègue, S., Pemonge, M.-H., Petit, R.J., 1998. Association between chloroplast and mitochondrial lineages in oaks. Mol. Biol. Evol. 15, 1321-1331.

Dumolin-Lapèque, S., Kremer, A., Petit, R.J., 1999. Are chloroplast and mitochondrial DNA variation species independent in oaks? Evolution 53, 1406-1413.

Dupouey, J.L., Badeau, V., 1993. Morphological variability of oaks (Quercus robur L., Quercus petraea (Matt.) Liebl., Quercus 
pubescens Willd.) in northeastern France: preliminary results. Ann. Sci. For. 50 (Suppl. 1), 35-40.

Fineschi, S., Taurchini, D., Grossoni, P., Petit, R.J., Vendramin, G.G., 2002. Chloroplast DNA variation of white oaks in Italy. For. Ecol. Manage. 156, 103-114.

Gaut, B.S., Morton, B.R., McCaig, B.C., Clegg, M.T., 1996. Substitution rate comparison between grasses and palms: synonymous rate differences at the nuclear gene Adh parallel rate differences at the plastid gene $r b c L$. Proc. Natl. Acad. Sci. USA 93, 10274-10279.

Gellini, R., Grossoni, P., 1997. Botanica Forestale, Vol. II: Angiosperme. CEDAM, Padova.

Gillham, N.W., 1994. Organelle Genes and Genomes. Oxford University Press, New York.

Gliemeroth, A.K., 1995. Paläoökologische Untersuchungen über die letzten 22.000 Jahre in Europa: Vebgetation, Biomasse und Einwanderungsgeschichte der wichtigsten Waldbäume. Gustav Fischer Verlag, Stuttgart.

Haas, J.N., Rasmussen, P., 1993. Zur geschichte der schneitel- und laubfutterwirtschaft in der schweiz. Eine alte landwirtschaftspraxis kurz vor dem aussterben. Discuss. Bot. 196, 469489.

Hengeveld, R., 1989. Dynamics of Biological Invasions. Chapman \& Hall, London.

Higgs, D.C., Kuras, R., Kindle, K.L., Wollman, F.A., Stern, D.B., 1998. Inversion in the Chlamydomonas chloroplast genome suppress a petD $5^{\prime}$ untranslated region deletion by creating functional chimeric mRNAs. Plant J. 14, 663-671.

Huntley, B., 1988. Europe. In: Huntley, B., Webb III, T. (Eds.), Vegetation History. Kluwer Academic Publishers, Dordrecht, pp. 341-384.

Jensen, J.S., Gillies, A., Csaikl, U.M., Munro, R., Madsen, S.F., Roulund, H., Lowe, A., 2001. Chloroplast DNA variation within the Nordic countries. For. Ecol. Manage., this issue.

Kanno, A., Lee, Y.O., Kameya, T., 1997. The structure of the chloroplast genome in members of the genome Asparagus. Theoret. Appl. Genet. 95, 1196-1202.

Keller, P., 1932. Der postglaziale eichenmischwald in der schweiz und den nachbargebieten. Beih. Bot. Ccl. 49, 176-204.

König, A.O., Ziegenhagen, B., van Dam, B.C., Csaikl, U.M., Coart, E., Degen, B., Burg, K., de Vries, S.M.G., Petit, R.J., 2002. Chloroplast DNA variation of oaks in western central Europe and the genetic consequences of human influences. For. Ecol. Manage. 156, 147-166.

Kral, F., 1979. Spät- und postglaziale waldgeschichte der alpen auf grund der bisherigen pollenanalysen. Institut für Waldbau, BOKU, Wien.

Kral, F., 1994. Der wald im spiegel der waldgeschichte Wien: eigenverlag autorengemeinschaft "Oesterreichs Wald". In: Oesterreichs Wald-Vom Urwald zur Waldwirtschaft/Österreichischer Forstverein [Hrsg.], pp. 11-40.

Küster, H., 1995. Geschichte der Landschaft in Mitteleuropa. Verlag C.H. Beck, München.

Küster, H., 1996. Auswirkung von klimaschwankungen und menschlicher landschaftsnutzung auf die arealverschiebung von pflanzen und die ausbildung mitteleuropäischer wälder. Forstwissenschaftliches Centralblatt 115, 301-320.
Küster, H., 1997. Die Rolle von Buche, Eiche und Hainbuche in der postglazialen Vegetationsgeschichte. Forstliche Forschungsberichte München Nr. 161. Universität München, Forstwissenschaftliche Fakultät, pp. 87-96.

Küster, H., 1997b. The role of farming in the post-glacial expansion of beech and hornbeam in oak woodlands of central Europe. The Holocene.

Landolt, E., 1977. Ökologische Zeigerwerte zur Schweizer Flora. Veröff. Geobot. Inst. Eidgenöss. Tech. Hochsch., Stift Rübel Zür, p. 64.

Le Corre, V., Dumolin-Lapègue, S., Kremer, A., 1997. Genetic variation at allozyme and RAPD loci in sessile oak Quercus petraea (Matt.) Liebl.: the role of history and geography. Mol. Ecol. 6, 519-529.

Leibundgut, H., 1991. Unsere waldbäume: eigenschaften und leben. 2. Aufl. Paul Haupt Verlag, Bern, pp. 91-100.

Lynch, M., Blanchard, J.L., 1998. Deleterious mutation accumulation in organelle genomes. Genetica 102, 29-39.

Markgraf, V., 1970. Paleohistory of the spruce in Switzerland. Nature 228, 249-251.

Markgraf, V., 1972. Die ausbreitungsgeschichte der fichte (Picea abies H. Kart.) in der schweiz. Berichte der Deutschen Botanischen Gesellschaft 85 (1-4), 165-172.

Mátyás, G., 1999. Rekonstruktion der nacheiszeitlichen einwanderung der eichen in der schweiz anhand ihrer chloroplastenDNA. Thesis. Diss. Nr. 13386, ETH Zürich, Switzerland.

Mátyás, G., Sperisen, C., 2000. Chloroplast DNA polymorphisms provide evidence for postglacial recolonisation of oaks (Quercus spp.) across the Swiss Alps. Theoret. Appl. Genet., in press.

Meyer, K.A., 1937. Holzartenwechsel und frühere verbreitung der eiche in der westschweiz. 2. Berner Jura. Mitt. eidgenöss. Forsch. Anst. Wald Schnee Landsch. 20, 445-511.

Müller, B., 1999. Variation und Hybridisierung von Quercus pubescens. Diss. Nr. 13025, ETH Zürich.

Olalde, M., Herrán, A., Espinel, S., Goicoechea, P.G., 2002. White oaks phylogeography in the Iberian peninsula. For. Ecol. Manage. 156, 89-102.

Patzelt, G., 1972. Die spätglazialen stadien und postglazialen schwankungen von ostalpengletschern. Ber. Deutsch. Bot. Ges. $85,47-57$.

Patzelt, G., 1980. Neue ergebnisse der spät- und postglazialforschung in tirol. Österr. Geogr. Ges. Jahresber. 76-77, 1118.

Petit, R.J., Kremer, A., Wagner, D.B., 1993. Geographic structure of chloroplast DNA polymorphisms in European oaks. Theoret. Appl. Genet. 87, 122-128.

Petit, R.J., Csaikl, U.M., Bordács, S., Burg, K., Coart, E., Cottrell, J., van Dam, B.C., Deans, J.D., Dumolin-Lapègue, S., Fineschi, S., Finkelday, R., Gillies, A., Glaz, I., Goicoechea, P.G., Jensen, J.S., König, A., Lowe, A.J., Madsen, S.F., Mátyás, G., Munro, R.C., Pemonge, M.-H., Popescu, F., Slade, D., Tabbener, H., Taurchini, D., de Vries, S.M.G., Ziegenhagen, B., Kremer, A., 2002. Chloroplast DNA variation in European white oaks: phylogeography and patterns of diversity based on data from over 2600 populations. For. Ecol. Manage. 156, $5-26$. 
Pignatti, S., 1982. Flora d'Italia. Edagricole, Bologna.

Pignatti, S., 1998. I boschi d'Italia. UTET, Torino.

Ralska-Jasiewicz, M., 1964. Correlation between the Holocene history of the Carpinus betulus and prehistoric settlement in North Poland. Acta Soc. Bot. Poloniae 33, 461-468.

Richoz, I., Haas, J.N., 1995. Flora und vegetation im schweizer mittelland und im Jura. In: Stöckli, W.E., Niffeler, U., GrossKlee, E. (Hrsg.), Die Schweiz vom Paläolithicum bis zum frühen Mittelalter. Basel, pp. 59-72.

Schadauer, K., 1994. Baumartenatlas für Österreich. FBVA-Berichte Nr. 76. Forstliche Bundesversuchsanstalt, Wien, 157 pp.
Taberlet, P., Gielly, L., Pautou, G., Bouvet, J., 1991. Universal primers for amplification of three non-coding regions of chloroplast DNA. Plant Mol. Biol. 17, 1105-1109.

Wolfe, P.G., Murray, R.A., Sipes, S.D., 1997. Species-independent, geographical structuring of chloroplast DNA haplotypes in a montane herb Ipomopsis (Polemoniaceae). Mol. Ecol. 6, 283291.

Zurawski, G., Clegg, M.T., Brown, A.H.D., 1984. The nature of nucleotide sequence divergence between barley and maize chloroplast DNA. Genetics 106, 735-749. 